\title{
Effect of Oil on Recruitment from the Seed Bank of Two Tidal Freshwater Wetlands
}

\author{
Mary Allessio Leck ${ }^{1}$ and Robert L. Simpson ${ }^{2}$ \\ 1 Biology Department, Rider College, Lawrenceville, NJ08648, U.S.A.; ${ }^{2}$ Office of the Provost, The University \\ of Michigan-Dearborn, Dearborn, MI 48128, U.S.A.
}

Keywords: Acnida cannabina, Bidens laevis, Delaware River, freshwater wetland, Impatiens capensis, oil spill, Peltandra virginica, recruitment, Sagittaria latifolia, seed bank, seedlings, tidal marsh

\begin{abstract}
The effect of oil spills on the recruitment of freshwater tidal wetland species was determined using soil seed bank samples collected in early March from two New Jersey Delaware River marshes. Samples were exposed to simulated tidal cycles 0 ( 2 days), 2 and 4 wk after soil was collected; 0 wk samples were treated before germination began. Oil treatment significantly reduced survival to 1 May (end of study) of Acnida cannabina and Bidens laevis, the dominant species, as well as number of species per sample and height of $B$. laevis. Total perennial seedlings, present in low numbers, also showed significant reduction with treatment. However, during the course of the study, Peltandra virginica recruitment and survival were not reduced by oil treatment and recruitment of Sagittaria latifolia appeared enhanced. There was no consistent pattern regarding which treatment time produced the greatest effect. Interactions (site, treatment, time) were generally not significant. Because these tidal freshwater wetlands and seed banks are dominated by annuals, reduction in seedling numbers and growth could substantially alter vegetation patterns. Timing of oil spills would be important, but impact would depend on species composition of the seed bank and colonizing vegetation, dispersal of seeds into the site, and germination requirements.
\end{abstract}

\section{Introduction}

According to Howarth (1989), the estimated amount of oil entering coastal areas worldwide, mostly from anthropogenic sources, is between 1.7-8.8 million metric tons $\mathrm{yr}^{-1}$. On the east coast of North America, oil spills in the lower Delaware River (e.g., Grand Eagle, 27 September 1985; Intermar Alliance, 19 March 1986; Presidente Rivera, 24 June 1989) have resulted in significant deposition of crude oil on emergent tidal wetland vegetation along $30 \mathrm{~km}$ of the New Jersey shoreline.

Effects of oil spills on vegetation have been studied in salt marshes (e.g., Cowell and Baker 1969; Baker
1971, 1973; Dicks 1975; Hampson and Moul 1978; and de la Cruz et al. 1981) and some freshwater wetlands (Burk 1977 and references cited therein). Following a spill, annual species often appear not to survive as well as perennials, presumably because they lack underground vegetative structures which can produce new growth (Daiber 1986). Thus, wetlands in which annuals are important could undergo dramatic shifts in species abundance and distribution in response to oil spills. Tidal freshwater wetlands are the only coastal wetlands that are often dominated by annuals (Simpson et al. 1983). These wetlands are extensive in the upper estuaries of most Atlantic and Gulf Coast river systems (Simpson et al. 1983; Odum 
et al. 1984). Their proximity to oil storage and refinery operations makes them especially susceptible to oil spills.

This study was designed to determine the effect of oil exposure on recruitment of tidal freshwater wetland species. Observations were made using soil samples from Woodbury Creek Marsh and Hamilton Marsh. These wetlands, located along the upper Delaware River estuary, have been the sites of several previous vegetation studies (e.g., Good and Good 1974-75; Whigham and Simpson 1975; Simpson et al. 1983; Leck et al. 1988). The dynamics of the seed bank, seedling populations, and vegetation composition of the Hamilton Marshes are wellknown (Leck and Graveline 1979; Parker and Leck 1985; Leck and Simpson 1987; Leck et al. 1988, 1989).

\section{Methods}

Sites

The Hamilton Marsh is located along a small tributary of Crosswicks Creek in Mercer County, NJ. Woodbury Creek Marsh is $60 \mathrm{~km}$ southwest in Gloucester County, NJ. The sites, each flooded for $3 \mathrm{hr}$ during a tidal cycle, are briefly described below. More information can be obtained from Simpson $e t$ al. (1983) and Good and Good (1974-75). Nomenclature follows Fernald (1970) except Zizania aquatica var. aquatica which follows Gleason (1952) and Phragmites australis which follows Godfrey and Wooton (1979).

Hamilton Marsh. The site is located near the mixed annuals site of Leck and Graveline (1979). Common annual species include Ambrosia trifida, Bidens laevis, Impatiens capensis, Polygonum arifolium and Z. aquatica var. aquatica. Perennials include Peltandra virginica and small numbers of $A$ corus calamus, Leersia oryzoides, Phalaris arundinacea and Sagittaria latifolia.

Woodbury Creek Marsh. The site is located in the Princeton-Jefferson section of the marsh described by Dubinski et al. (1986) and is dominated by mixed aquatics (Good and Good 1974-75). Common annuals include Acnida cannabina, A. trifida, B. laevis, $Z$. aquatica var. aquatica, in addition to the perennial $S$. latifolia.

\section{Soil Samples}

Fifty-six surface soil samples were collected on 7 March (Hamilton Marsh) and 8 March 1987 (Woodbury Creek Marsh), prior to field germination. At each site samples were collected from an area which appeared homogeneous in the amount and composition of litter. Samples $(19.5 \mathrm{~cm} \times 19.5 \mathrm{~cm} \times 6.5 \mathrm{~cm}$ deep) were cut from the wetland surface and placed into plastic trays of the same size with minimal disturbance. For each site, collection of samples, transport to, and placement in the greenhouse was accomplished within six hours. Except when samples received tidal treatment, they were maintained on a greenhouse bench. Greenhouse conditions during the study included ambient photoperiod, $\sim 30 \%$ solar irradiance, and a temperature range of 7 to $25^{\circ} \mathrm{C}$. Samples were kept saturated with distilled water.

Samples from each site were randomly distributed into seven treatment groups with eight samples per group. Three groups were subjected to five consecutive tidal cycles (procedures described below) in tanks containing crude oil on the water surface, and three other groups were subjected to the same tidal regime, but without oil. Tidal treatments were begun two days ( 0 wk), 2 wk and 4 wk after sample collection. A control group received no tidal manipulation and no oil.

Tidal treatments were carried out in plexiglas tanks ( $60 \mathrm{~cm} \mathrm{x} 82 \mathrm{~cm} \mathrm{x} 21 \mathrm{~cm}$ deep) sized to permit simultaneous treatment of a set of eight replicates. The plastic trays containing soil samples were placed on $2 \mathrm{~cm}$ thick bars positioned on the bottom of tanks to ensure drainage. Then tap water, aged 12 hours, was added at the rate of $1 \mathrm{~cm}$ per minute to a depth of $8.5 \mathrm{~cm}$ above the surface of the soil; the total water depth in each tank was $17 \mathrm{~cm}$. For the 0 and $2 \mathrm{wk}$ treatments, water level was above most seedlings. Inundation lasted $3 \mathrm{hr}$, after which water was drained from the tanks.

In oil treatment tanks, a $1 \mathrm{~cm}$ layer of oil was poured onto the surface of $2.5 \mathrm{~cm}$ of water and allowed to stand overnight. Trays were placed on the 
bars and water was added as above. When the water was drained, some oil remained on the surface of the soil and plants in the trays, but most collected in the bottom of the tank.

Each treatment involved five consecutive tidal cycles which, for convenience, were $12 \mathrm{hr}$ apart (natural cycles are $11.5 \mathrm{hr}$ apart). When temperatures were $<10^{\circ} \mathrm{C}$ during treatment, the oil assumed a tar-like consistency and did not completely cover the sample surface upon drawdown. Continuous cool weather during treatment of 0 wk Woodbury Creek Marsh samples resulted in $38 \pm 6 \%$ of the soil surface being free of oil.

\section{Seedling evaluation}

Seedling numbers were determined at the time of treatment (except the 0 wk groups which were treated prior to germination), a week after treatment, and/or at 2 wk intervals until 1 May. Few seedlings remained unidentified $(<0.2 \% ; \mathrm{n}=14$ for Hamilton Marsh samples and $n=8$ for Woodbury Creek Marsh). Because seedlings were not removed from samples soon after germination, it was occasionally difficult to determine whether grass shoots were from seeds or vegetative growth. Grasses were not distinguished to species, but tentative identification was based on species present at or near each site.

Bidens laevis, the only abundant species common to both sites, was used to determine the effects of oil treatment on growth. Ten seedlings per replicate were marked following 0 and 2 wk treatments or at 3 wks for controls. No measurements were made for 4 wk treated samples because oil had caused plants to collapse, making it too difficult to select plants to measure. Height measurements made on 1 May are reported.

\section{Statistical analyses}

Multivariate analysis of variance (MANOVA), coupled with Duncan's multiple range test (SAS Institute Incorporated 1985), was used to compare site (Hamilton Marsh, Woodbury Creek Marsh); treatment (control, tidal-oil, tidal-no oil); and time (con- trol, 0, 2 and $4 \mathrm{wk}$ ) interactions for maximum number of seedlings (i.e., the largest number recorded on any given date), for number of seedlings surviving on 1 May, and for percent of maximum surviving on 1 May (for A. cannabina, B. laevis, I. capensis, perennials, number of species per sample and total seedlings). The same statistical procedures were used for B. laevis height data. Arcsine transformation was used to normalize percentage data prior to analysis. Percent similarity was calculated using Pielou (1984). The Likelihood Ratio Chi-Square (SAS Institute Incorporated 1985) was used to compare treatment effects on survival of perennials and $B$. laevis height measurements.

\section{Results}

Seventeen species were recorded from Hamilton Marsh soil samples and 19 from Woodbury Creek Marsh samples. The mean number of species per sample ranged from $3.3 \pm 0.3$ to $9.3 \pm 0.4$ (Table l). Hamilton Marsh soil samples had significantly more species per sample (Table 2). Of the 25 species, 11 were common to both sites, giving $61 \%$ similarity. There were no site differences for total number of seedlings (maxima and numbers surviving to 1 May) or number of species per sample surviving to 1 May (Table 2).

Oil treatment significantly decreased the numbers and percent of total seedling survival (until 1 May) in samples from both sites (Tables 1 and $2 ; \mathrm{P} \leq .001$ ). Oil treatment also significantly reduced the numbers and percent survival to 1 May of A. cannabina, B. laevis, I. capensis, perennials and number of species per sample (Table 2). For most parameters, time of treatment caused significant $(\mathrm{P} \leq .001)$ but variable effects; percent survival of total seedlings was highest in control samples and lowest when samples were treated at 2 or 4 wk (Table 2). Two- and three-way interactions were generally not significant except for $B$. laevis, perennial survival and maximum number of perennials (Table 2).

Percent survival of $A$. cannabina, B. laevis and $I$. capensis according to site and treatment are shown in Fig. 1. Few A. cannabina germinated in Hamilton Marsh samples and $I$. capensis germination was low 
Table 1 . Effect of tidal treatment, with and without oil, on wetland recruitment. Values are $\bar{x} \pm S E$ for maximum seedling density, percent of maximum surviving to $1 \mathrm{May}$, maximum perennial seedling density, percent of maximum perennials surviving to $1 \mathrm{May}$, maximum species per sample, and species per sample surviving to I May. Also presented is the proportion of the most common species ( $\bar{x} \% \pm S E$ ). ( 0 wk treatment occurred before germination had begun; except for 0 wk, maximum numbers include pretreatment values).

\begin{tabular}{|c|c|c|c|c|c|c|c|c|}
\hline & $\begin{array}{c}\text { Maximum } \\
\text { Seedling } \\
\text { Density }\left(\mathbf{m}^{-2}\right)^{1}\end{array}$ & $\begin{array}{c}\% \\
\text { Surviving }\end{array}$ & $\begin{array}{l}\% \text { Most } \\
\text { Common } \\
\text { Species }^{2}\end{array}$ & $\begin{array}{c}\text { Maximum } \\
\text { Perennial } \\
\text { Density }\left(\mathbf{m}^{-2}\right)\end{array}$ & $\begin{array}{c}\text { \% } \\
\text { Perennials } \\
\text { Surviving }\end{array}$ & $\begin{array}{c}\text { Total } \\
\text { Species }\end{array}$ & $\begin{array}{l}\text { Species } \\
\text { Surviving }\end{array}$ & $\begin{array}{l}\% \text { Species } \\
\text { Surviving }\end{array}$ \\
\hline \multicolumn{9}{|c|}{ HAMILTON MARSH } \\
\hline oil $0 w k$ & $3143 \pm 333$ & $52 \pm 3$ & 97 & $43 \pm 8$ & $63 \pm 18$ & $3.9 \pm 0.5$ & $3.3 \pm 0.5$ & $85 \pm 6$ \\
\hline oil $2 w k$ & $4119 \pm 399$ & $13 \pm 3$ & 92 & $99 \pm 17$ & $42 \pm 15$ & $5.9 \pm 0.4$ & $1.8 \pm 0.2$ & $32 \pm 5$ \\
\hline oil 4 wk & $4347 \pm 277$ & $14 \pm 2$ & 84 & $283 \pm 46$ & $48 \pm 10$ & $7.5 \pm 0.4$ & $3.4 \pm 0.4$ & $47 \pm 6$ \\
\hline no oil 0 wk & $4855 \pm 317$ & $77 \pm 2$ & 89 & $158 \pm 23$ & $86 \pm 1$ & $8.8 \pm 0.6$ & $6.5 \pm 0.3$ & $76 \pm 4$ \\
\hline no oil 2 wk & $4645 \pm 329$ & $87 \pm 5$ & 88 & $256 \pm 53$ & $91 \pm 4$ & $9.1 \pm 0.4$ & $6.9 \pm 0.4$ & $76 \pm 3$ \\
\hline no oil 4 wk & $5631 \pm 436$ & $73 \pm 4$ & 84 & $266 \pm 37$ & $96 \pm 2$ & $9.3 \pm 0.4$ & $6.6 \pm 0.5$ & $72 \pm 5$ \\
\hline control & $3912 \pm 218$ & $83 \pm 7$ & 82 & $362 \pm 24$ & $94 \pm 3$ & $8.8 \pm 0.4$ & $6.4 \pm 0.3$ & $80 \pm 3$ \\
\hline \multicolumn{9}{|c|}{ WOODBURY CREEK MARSH } \\
\hline oll $0 \mathrm{wk}$ & $2825 \pm 308$ & $77 \pm 3$ & 98 & $53 \pm 16$ & $69 \pm 16$ & $3.3 \pm 0.3$ & $3.1 \pm 0.2$ & $97 \pm 3$ \\
\hline oil 2 wk & $3843 \pm 886$ & $16 \pm 4$ & 93 & $135 \pm 26$ & $40 \pm 9$ & $6.4 \pm 0.5$ & $3.5 \pm 0.3$ & $55 \pm 4$ \\
\hline oil 4 wk & $5056 \pm 525$ & $36 \pm 5$ & 93 & $56 \pm 24$ & 0 & $5.6 \pm 0.4$ & $4.1 \pm 0.4$ & $77 \pm 9$ \\
\hline no oil $0 w k$ & $4747 \pm 759$ & $92 \pm 5$ & 92 & $164 \pm 34$ & $76 \pm 14$ & $5.9 \pm 0.6$ & $5.4 \pm 0.5$ & $92 \pm 3$ \\
\hline no oil 2 wk & $4241 \pm 600$ & $80 \pm 9$ & 94 & $53 \pm 15$ & $50 \pm 16$ & $6.3 \pm 0.8$ & $5.9 \pm 0.7$ & $93 \pm 4$ \\
\hline no oil 4 wk & $5191 \pm 429$ & $74 \pm 8$ & 91 & $89 \pm 37$ & $53 \pm 17$ & $6.4 \pm 0.5$ & $5.8 \pm 0.4$ & $92 \pm 5$ \\
\hline control & $3508 \pm 284$ & $90 \pm 4$ & 89 & $66 \pm 15$ & $76 \pm 10$ & $6.8 \pm 0.3$ & $6.4 \pm 0.3$ & $92 \pm 5$ \\
\hline
\end{tabular}

1 Maxımum = largest number recorded for any given date.

2 Bidens laevis for Hamilton Marsh samples and B. laevis and Acnida cannabina for Woodbury Creek Marsh samples.

'Seedlıng species (* = perennials) common to both sites were: Acnida cannabina, Bıdens laevis, Callitriche heterophyla, Cicuta maculata*, Cuscuta gronovii, Gratiola neglecta, Impatiens capensis, Plea pumila, Polygonum arffolium, Polygonum punctatum, and Sagittaria latifolia*. Species found only in Hamilton Marsh samples were: Ambrosia trifida, Erechtites hieracifolia, Peltandra virgunica*, Typha latifolia*, Gramineae (Phalarıs arundinacea* and possibly Leersia oryzordes*), and one unknown. Species only in Woodbury Creek Marsh samples were: Cornus amomum*, Polygonum sagittatum, Polygonum sp., Typha angustifolia*, Zizania aquatica var. aquatica, Gramineae (Pragmites australis*), and two unknown species.

in both marsh samples. Except for $A$. cannabina from Hamilton Marsh, seedling survival in all samples not treated with oil exceeded $50 \%$ (see also Table 1). As indicated by MANOVA (Table 2) efficacy of time of treatment varied with species: $B$. laevis showed increasing impact of oil treatment with time ( 4 wk $>2$ wk $>0$ wk); A. cannabina from Woodbury Creek Marsh showed lowest percent survival when treated with oil at $2 \mathrm{wk}$; and $I$. capensis appeared to survive best when treated at 4 wk. However, it should be noted that even though seedlings of these and other species, survived oil treatment for the duration of the experiment, they often appeared stunted and chlorotic.

Height of $B$. laevis seedlings was significantly reduced by oil treatment (Table 2 and Fig. 2). Those from Woodbury Creek Marsh samples were signifi- cantly taller than those from Hamilton Marsh (Fig. 2 and Table 2). Survival of these marked seedlings was significantly reduced $(\mathrm{P} \leq .001)$ by oil treatment.

The impact of oil was also variable among perennials (Table 3). Peltandra virginica and, to a lesser extent, S. latifolia appeared to tolerate oil treatment, whereas Typha latifolia and grasses had reduced seedling recruitment and survival. Interestingly, $S$. latifolia germination appeared enhanced by oil treatment but numbers were too small for Likelihood ChiSquare analysis.

With the exception of 0 wk oil treatment groups, all tidal treatments had more seedlings than the controls (Table 1). For many parameters (Table 2), the no oil treatment values were greater than control values, although often statistically similar. This and the statistically significant greater total seedling sur- 
Tahle 2. MANOVA and Duncan's multiple range test results for effects of tidal treatment, with and without oil, on seed bank recruitment and Bidens laevis height data '

\begin{tabular}{|c|c|c|c|c|c|c|c|}
\hline & SITE & TREAT & TIME & SxTr & $\mathrm{SxT}_{1}$ & $\operatorname{Tr} x \operatorname{Ti}$ & SxTrxTi \\
\hline Acnuda $(\max )^{2}$ & WH & n.s & $4 \underline{2 \mathrm{C} 0} * *$ & n.s. & ** & n.s & n.s. \\
\hline A(nida (I May) & WH & $\mathrm{N} \overline{\mathrm{CO}}$ & n.s. & $* * *$ & n s. & n.s & n.s. \\
\hline Acnıda ( ${ }_{C}^{\circ}$ surviving) & WH & $\mathrm{NCO}$ & n.s. & n.s. & n.s. & n.s. & ns. \\
\hline Budens (max) & $\mathrm{HW}$ & $\overline{\mathrm{NOC}}$ & n.s. & n.s. & $* * *$ & n s. & n.s. \\
\hline Bldens (I May) & $\mathrm{HW}$ & $\underline{\mathrm{NCO}}$ & $\underline{0 C} \overline{24}$ & $* * *$ & * & $*$ & n.s. \\
\hline Bidens ( ${ }^{\prime}$ surviving) & $\mathrm{WH}^{*}$ & C N O & C 024 & n.s. & n.s & ** & n.s. \\
\hline Impatiens (max) & WH & $\mathrm{N} \overline{\mathrm{CO}^{*}}$ & $4 \mathrm{C} \overline{20}$ & n.s. & n.s. & n.s. & n.s. \\
\hline Impatıens (I May) & WH** & $\overline{\mathrm{NC}} \mathrm{O}$ & $4 \overline{C \overline{02}}$ & n.s. & n.s. & n.s. & n.s. \\
\hline Impattens ( ${ }^{\circ}$ surviving) & n.s & $\mathrm{NCO}$ & $\mathrm{C} 4 \overline{20}$ & n.s. & n.s. & $*$ & n.s. \\
\hline Perennials (max) & HW & $\mathrm{CNO}$ & $C \overline{4} 20^{* *}$ & $* * *$ & *** & * & $* *$ \\
\hline Perennials ( 1 May) & $\mathrm{HW}$ & $\underline{\mathrm{CNO}}$ & n.s. & $* * *$ & $* * *$ & n s. & n.s. \\
\hline Perennials ( $\sigma_{C}$ surviving) & $H W * *$ & $\overline{\mathrm{CN}} \mathrm{O}$ & C $\overline{02} 4^{*}$ & n.s. & * & n.s. & n.s \\
\hline No. species/sample (max) & $\mathrm{HW}$ & $\underline{\mathrm{NCO}}$ & $\mathrm{C} 420$ & **** & n.s. & $* * *$ & n.s \\
\hline No. species/ sample (I May) & n.s. & $\underline{\mathrm{CNO}}$ & n.s. & $* *$ & n.s. & n.s. & n.s. \\
\hline No. species/sample (\%r surviving) & WH & $\overline{\mathrm{CN}} \mathrm{O}$ & $0 \mathrm{C} \overline{42}$ & n.s. & n.s & $* * *$ & n.s. \\
\hline Total seedlings (max) & n.s & $\mathrm{NOC}$ & $4 \underline{20 C^{* *}}$ & n.s. & n.s. & n.s. & n.s. \\
\hline Total seedlings ( 1 May) & n.s. & $\mathrm{NCO}$ & $\mathrm{C}^{04} \overline{4}^{*}$ & n.s. & $\mathrm{n} . \mathrm{s}$ & n.s. & n.s. \\
\hline Total seedlings ( $c_{0}$ surviving) & WH & $\mathrm{CNO}$ & $\mathrm{CO} 24$ & n.s. & $*$ & **** & n.s. \\
\hline Budens height & WH & $\overline{\mathrm{CNO}}$ & $\mathrm{C} 02$ & n.s. & n.s & n.s. & n.s. \\
\hline
\end{tabular}

1 All site, treatment, and time differences were significant at $\left.\mathrm{P} \leq .001{ }^{* * *}\right)$ unless otherwise indicated as follows: * $=05>\mathrm{P}>01$; **=01>P $>.001 ;$ n.s. = not significant. Groups are ranked from largest to smallest; those underlined are not significantly different $(P \leq .05)$. Sites $\mathrm{H}=$ Hamilton Marsh and $\mathrm{W}=$ Woodbury Creek Marsh; Treatments $\mathrm{O}=$ tıdal oil, $\mathrm{N}=$ tidal no oll, and $\mathrm{C}=$ non-tidal control; Time 0, $2,4=2$ days, 2 wks, and 4 wks following collection and $\mathrm{C}=$ non-tidal control.

$2 \mathrm{Max}=$ greatest number recorded on any given date, 1 May $=$ number of seedlıngs alive on $1 \mathrm{May} ; \sigma_{0}^{\circ}$ survivıng $=1 \mathrm{May} / \mathrm{max} \times 100$.

vival to 1 May in no oil compared with control samples, suggest that tidal inundation was beneficial.

\section{Discussion}

The Hamilton and Woodbury Creek Marshes are dominated by annual species. Yearly biomass production of annuals may be high $\left(2346 \mathrm{~g} \mathrm{~m}^{-2} \mathrm{yr}^{-1}\right.$ to $>$ $6000 \mathrm{~g} \mathrm{~m}^{-2} \mathrm{yr}^{-1}$; Whigham et al. 1978; Sickels and Simpson 1985) with cover ranging from 75 to $90 \%$ (Leck and Simpson, unpublished data). In such wetlands, oil spills would have considerable impact on vegetation dynamics. Spills occurring after germination would be especially damaging (Table 1 ; Table 2 , $\%$ survival data). We found significant reduction in seedling number, number of species (Tables 1 and 2), and growth (e.g., B. laevis, Fig. 2), but impact varied with species (Fig. 1).

Field observations have shown that oil spills in winter can cause reduced spring germination (Baker
1971). Time of treatment significantly affected most parameters in our study (Table 2) yet there was no one time which had the greatest effect. Higher percent seedling survival of the 0 wk treatment (just prior to germination) compared with later oil exposure (Table 1) can, at least in part, be attributed to poor coverage of the soil surface by congealed oil at low temperatures. Thus, there were unaffected patches where recruitment could occur. It is possible that in the field, tidal activity could cause redistribution of oil (see Daiber 1986) further reducing germination and/or survival. In addition, tides can cause continuous uncovering of oil from sediments and lead to long-term contamination (Stickney 1984).

The timing of an oil spill may determine vegetation recovery in a variety of ways. If the seed bank of a species is already depleted by spring germination (e.g., I. capensis; Leck and Simpson 1987), there can be no subsequent recruitment, even if oiled surfaces crack, exposing uncontaminated soil (e.g., Stebbings 1970). Other species with persistent seed banks (e.g., 


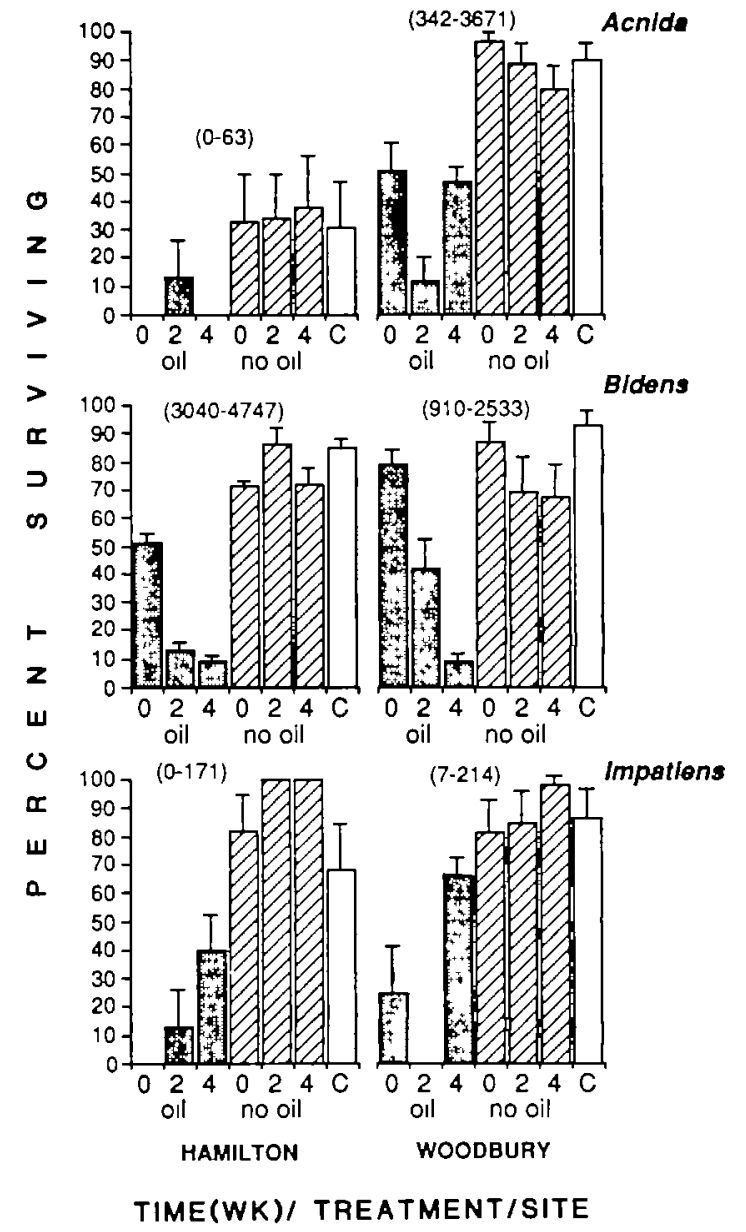

Figure 1. Percent survival ( $\overline{\mathrm{x}} \pm \mathrm{SE}$ ) of Acnida cannabina, Bidens laevis, and Impattens capensis seedlings to I May in samples from Hamilton Marsh and Woodbury Creek Marsh. Numbers indicate density $\left(\mathrm{m}^{-2}\right)$ range for each site. $\mathrm{C}$ is the control.

B. laevis or A. cannabina; Leck and Simpson 1987) or those with continual dispersal ( Typha spp.) could take advantage of reduced competition. Gaps in the oil (e.g., cracks and other surface disturbances) may provide specific germination requirements such as improved light (e.g., Typha; Sifton 1959) and light and aeration (e.g., B. laevis; Leck, unpublished data). Other species may respond to seasonally higher temperatures (e.g.. Malvaceae; Baskin and Baskin 1989).

The impact of oil on wetland seed germination may be attributed to oil on seeds acting as a physical barrier to water and oxygen, or, if it penetrates the seed, toxicity to embryos (Amakiri and Onofeghara

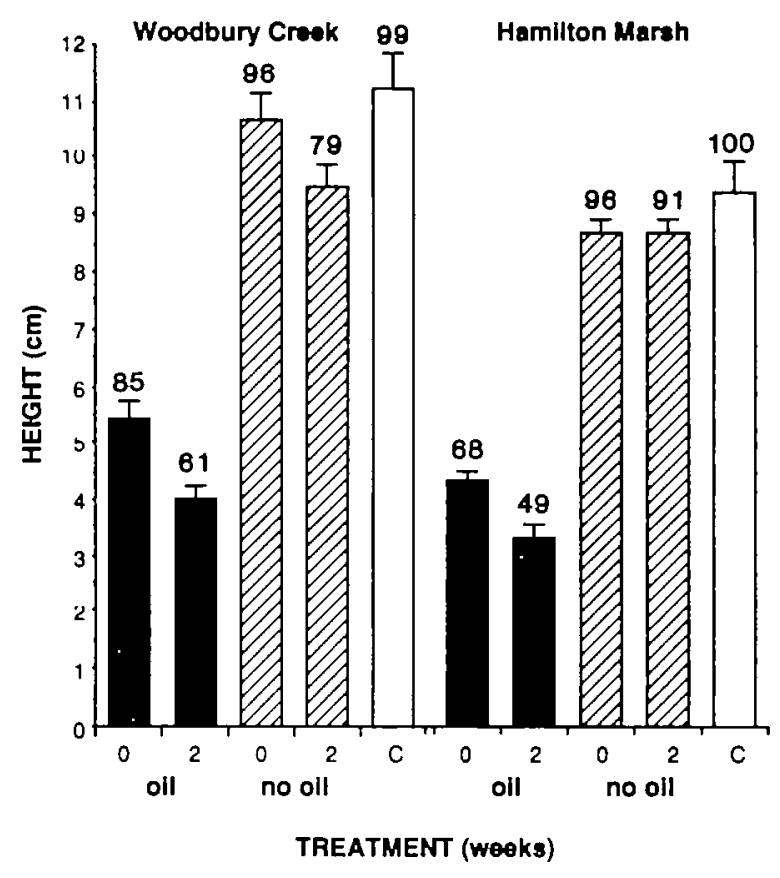

Figure 2. Height of Bidens laevis $(\overline{\mathrm{x}} \pm \mathrm{SE})$ from both marshes measured on 1 May. Numbers above each bar indicate percent survival. $\mathrm{C}$ is the control.

1984); Daiber 1986). Moreover, effect on recruitment from the seed bank would depend on the extent to which oil penetrates and/or covers the wetland surface, distribution of seeds in the soil profile and subsequent exposure to favorable germination conditions, and seed characteristics of the component species.

As noted elsewhere (e.g., Dicks 1975; Baker 1979; Daiber 1986), species differed in their tolerance to oil (Fig. 2 and Table 3). Bidens laevis percent survival decreased from 0 to 2 to 4 wk (Fig. 1), but a similar pattern was not observed for $A$. cannabina (Fig. 1) or I. capensis. Oiled $I$. capensis seedlings had improved survival at 4 wk. However, oiled seedlings were not as vigorous as no oil or control plants. The unhealthy appearance of all oil treated plants still surviving on 1 May suggested that plants would be capable of little, if any, reproductive output.

The responses of perennial species to oil treatment varied (Table 3) and likely were related to seed and seedling characteristics. Peltandra virginica survival was unaffected by oil treatment. Of the perennials present, it has the largest seeds $(1 \mathrm{~cm})$ and seedlings. 
Table 3. Frequency, $\%$ survival ( $\mathrm{x} \pm \mathrm{SE}$ ), and Least Likelihood Chi-Square (LLX $\left.{ }^{2}\right)$ analysis for perennials.

\begin{tabular}{|c|c|c|c|c|c|c|c|}
\hline & \multicolumn{2}{|c|}{ Onl } & \multicolumn{2}{|c|}{ No Oll } & \multicolumn{2}{|c|}{ Control } & \multirow[b]{2}{*}{ LLX2 } \\
\hline & $\begin{array}{c}\text { Frequency' } \\
\left(c^{\prime \prime}()^{\prime}\right)\end{array}$ & Surviving & $\begin{array}{c}\text { Frequency } \\
\left(c^{\prime}\right)\end{array}$ & $\begin{array}{c}c_{e}^{\prime} \\
\text { Surviving }\end{array}$ & $\begin{array}{c}\text { Frequency } \\
\left({ }^{\left({ }^{\prime}\right.}\right)\end{array}$ & Surviving & \\
\hline \multicolumn{8}{|c|}{ HAMILTON MARSH } \\
\hline Pellandra virgınica & 75 & $9.3 \pm 6$ & 71 & $94 \pm 6$ & 50 & 100 & n.s. \\
\hline Sagntaria latifolia & 17 & $50 \pm 29$ & 0 & 0 & 0 & 0 & 2 \\
\hline Tipha latifolaa & 21 & $20 \pm 20$ & 79 & $59 \pm 10$ & 75 & $64 \pm 17$ & n.s. \\
\hline grasses & 63 & 0 & 96 & $93 \pm 3$ & 100 & 100 & $<.001$ \\
\hline other & 0 & 0 & 1.3 & 100 & 0 & 0 & \\
\hline \multicolumn{8}{|c|}{ WOODBURY CREEK MARSH } \\
\hline Sagntarara latesolia & 46 & $86 \pm 8$ & 4 & 100 & 0 & 0 & - \\
\hline$T_{1 p h a}$ augustifolia & 4 & 0 & 4 & 0 & 0 & 0 & \\
\hline glasues & 63 & $18 \pm 9$ & 75 & $75 \pm 9$ & 88 & $74 \pm 11$ & $<.00 \mathrm{I}$ \\
\hline other & 0 & 0 & 8 & 100 & 0 & 0 & \\
\hline
\end{tabular}

1 Frequency based on samples from all treatment dates

Numbers were too small for analysis

Within the single-seeded fruits, its seeds are covered with mucilage (West and Whigham 1975-1976). These features no doubt contributed to its high survival rate. Greater germination of S. latifolia in oil treated samples may have been caused by lowered soil oxygen. In an earlier Hamilton Marsh study (Leck and Simpson 1987), S. latifolia germination was significantly greater in flooded than nonflooded samples. In contrast, the susceptibility of grasses and Typha to oil exposure may be related to small seed and/or seedling size, and oxygen and light requirements for germination.

These Delaware River tidal freshwater marshes have considerable yearly turnover in the seed bank (Leck and Simpson 1987) because the annual-dominated vegetation is recruited from the seed bank (Parker and Leck 1985; Leck et al. 1989). In addition, the composition of the vegetation reflects that of the seed bank (Parker and Leck 1985; Leck and Simpson 1987). Thus, even a single oil spill could destroy or substantially alter vegetation patterns. The effect would be especially dramatic if the transient seed bank is not replenished by seed production or by dispersal, a likely result if seedling mortality is high following an oil spill. Colonization following an oil spill could shift seed bank composition, favoring species with persistent seed banks or the best dispersal. However, in situ deposition could alter recruitment from the seed bank or impact of dispersal by affect- ing seed and/or oil burial rates. (Rate of sedimentation has been estimated to be $1 \mathrm{~cm} \mathrm{yr}^{-1}$ at Woodbury Creek Marsh; Orson et al. 1990).

If disturbance caused by oil is widespread or longterm, the extent and development of vegetation could be limited (see Dicks 1975). Following the Amoco Cadiz spill on the northwest coast of France, natural revegetation did not occur because germination was inhibited (Levasseur and Jory 1982; cited in Daiber 1986). Similarly, in a Massachusetts salt marsh, Spartina alterniflora did not re-establish by reseeding in the lower intertidal zone within $3 \mathrm{yr}$ after an oil spill (Hampson and Moul 1978). Along the Connecticut River in a nontidal freshwater marsh, effects of oil varied with zone. High marsh and midmarsh zones recovered after 3-4 yr, but there was a reduction in species diversity in the low marsh (Burk 1977). In addition, extensive loss of vegetation could lead to subsequent erosion of the wetland surface (Orson, Simpson and Good, pers. comm.). Lack of litter also precludes seed entrappment and subsequent establishment (Daiber 1986).

If a spill were to eliminate recruitment and reproduction of annual species, we feel that species with persistent seed banks and ability to germinate throughout the growing season, such as $A$. cannabi$n a$ and $B$. laevis, or perennials with widespread and summer dispersal, such as Typha spp. or P. arundinacea, could colonize gaps as they occur. Others, 
such as $P$. virginica and $S$. latifolia with more tolerant seed/seedling characteristics may reinvade more quickly than annuals.

Future studies suggested by our work include the impact of oil treatment on reproductive output of annual species, effect of vegetation and litter loss on seed entrappment and establishment, and the importance of substrate characteristics in determining oil effect on recruitment. In addition, the suggestion (Tables 1 and 2) that recruitment was enhanced by tidal treatment merits further examination; a study of Distichlis spicata germination showed rhythms in germinability (Hadden 1970).

The overall impact of an oil spill would depend on the timing and magnitude of the spill; composition and transient/persistent nature of the seed bank; germination requirements; effect of oil on the seed bank, seedlings, adult plants, and sexual reproduction; dispersibility of species; and wetland soil characteristics. Although the impact on vegetation can be minimal (DeLaune, et al. 1984), our results showed that oil spills can have significant short-term effects on seedling establishment and growth that may translate into long-term effects on composition. We support Stickney's (1984) contention that "a single significant oil spill in a given estuary will have longterm effects that cannot be ignored".

\section{Acknowledgments}

We thank Sun Oil Company and Kurt Philipp for supplying the oil. Gigi Beretta, Julie Chang, Frederick Sickels, Mark Tulaba and Barbara Wetherald assisted in the field and/or greenhouse. Peter Morin and David Campbell helped with statistical analyses. Comments by Dennis Whigham and reviewers resulted in substantial improvements. Mary Kildea typed the manuscript and Richard Orson prepared the figures.

\section{References}

Amakiri, J.O. and Onofeghara, F.A. 1984. Effects of crude oil on the germination of Zea mays and Capsicum frutescens. Environ. Pollut. 35: 159-167.

Baker, J.M. 1971. Seasonal effects of oil pollution on salt marsh vegetation. Oikos 22: 106-110.

Baker, J.M. 1973. Recovery of salt marsh vegetation from successive oil spillages. Environ. Pollut. 4: 223-230.

Baker, J.M. 1979. Responses of salt marsh vegetation to oil spills and refinery effluents. pp. 529-542. In: Ecological Processes in Coastal Environments. Edited by R.L. Jefferies and A.J. Davy. Blackwell, Oxford, England.

Baskın, J.M. and Baskin, C.C. 1989. Physiology of dormancy and germination in relation to seed bank ecology. pp. 53-66. In: Ecology of Soil Seed Banks. Edited by M.A. Leck, V.T. Parker and R.L. Simpson. Academic Press, San Diego, California, U.S.A.

Burk, C.J. 1977. A four year analysis of vegetation following an oil spill in a freshwater marsh. J. Appl. Ecol. 14: 515-522.

Cowell, E.B. and Baker, J.M. 1969. Recovery of a salt marsh in Pembrokeshire, South-west Wales, from pollution by crude oil. Biol. Conserv. 1: 291-295.

Daiber, F.C. 1986. Conservation of Tidal Marshes. Van Nostrand Reinhold, New York, New York, U.S.A. 341 pp.

de la Cruz, A.A., Hackney, C.T. and Rajanna, B. 1981. Some effects of crude oil on a Juncus tidal marsh. J. Elisha Mitchell Scientific Soc. 97: 14-28.

DeLaune, R.D., Smith, C.J., Patrick, W.H., Jr., Fleeger, J.W. and Tolley, M.D. 1984. Effect of oil on salt marsh biota: methods for restoration. Environ. Pollut. 36: 207-227.

Dicks, B. 1975. Changes in the vegetation of an oiled Southhampton water salt marsh. pp. 208-240. In: Recovery and Restoration of Damaged Ecosystems. Edited by J. Cairns, Jr., K.L. Dickson and E.E. Herricks. University Press of Virginia, Charlottesville, Virginı, U.S.A.

Dubinsk1, B.J., Simpson, R.L. and Good, R.E. 1986. The retention of heavy metals in sewage sludge applied to a freshwater tidal wetland. Estuaries 9: 102-111.

Fernald, M.A. 1970. Gray's Manual of Botany. (Eighth edition). D. Van Nostrand Company, New York, New York, U.S.A. $1632 \mathrm{pp}$.

Gleason, H.A. 1952. The New Britton and Brown Illustrated Flora of the Northeastern United States and Adjacent Canada. Hafner Press, New York, New York, U.S.A. Vol. 1. 482 pp.

Godfrey, R.K. and Wooton, J.W. 1979. Aquatic and Wetland Plants of Southeastern United States. University of Georgia Press, Athens, Georgia, U.S.A. 550 pp.

Good, R.E. and Good, N.F. 1974-75. Vegetation and production of the Woodbury Creek-Hessian Run freshwater tidal marshes. Bartonia 43: 38-45.

Hadden, E.L., Jr. 1970. Studies on the variable germinability of seeds of Distichlis spicata (L.) Greene. Masters Thesis. Wake Forest University, Winston-Salem, North Carolina, U.S.A. 30 pp. 
Hampson, G.R. and Moul, E.T. 1978. No 2 fuel oil spill in Bourne, Massachusetts: immediate assessment of the effects on marine invertebrates and a 3-year study of growth and recovery of a salt marsh. J. Fish. Res. Board Can. 35: 731-744.

Howarth, R.W. 1989. Determıning the ecological effects of oll pollution on marine ecosystems. pp. 69-97. In: Ecotoxicology: Problems and Approaches. Edited by S.A. Levin, M.A. Harwell, J.R. Kelly and K.D. Kimball. Springer-Verlag, New York, New York. U.S.A.

Leck, M.A. and K J Graveline. 1979. The seed bank of a freshwater tidal marsh. Amer. J. Bot. 66: 1006-1015.

Leck, M.A. and Simpson, R.L. 1987. Seed bank of a freshwater tidal wetland: turnover and relationship to vegetation change. Amer. J. Bot. 74: 360-370.

Leck, M A , Simpson, R.L., Whigham, D F. and Leck, C.F. 1988. Plants of the Hamilton Marshes: a Delaware River freshwater tidal wetland. Bartonia 54: 1-17.

Leck, M.A., Simpson, R.L. and Parker, V.T. 1989. The seed bank of a freshwater tidal wetland and its relationship to vegetation dynamıcs. pp. 189-205. In: Freshwater Wetlands and Wildlife. Edited by R.R. Sharitz and J.W. Gibbons. CONF-8603101. USDOE Off. Sci. Tech. Info. 1265 pp.

Odum, W.E., Smith, T.J., Hoover, J.K., and Mclvor, C.C. 1984. The Ecology of Tidal Freshwater Marshes and the United States East Coast: A Community Profile FWS/OBS-83/17 National Coastal Ecosystem Team, Fish and Wildlife Service, United States Department of Interior, Washington, DC, U S A.

Orson, R.A., Simpson, R.L., and Good, R.E. 1990. Rates of sediment accumulation in a tidal freshwater marsh. J. Sedimentary Petrology 60. 859-869.

Parker, V.T. and Leck, M.A. 1985. Relationshıp of seed banks to plant distribution patterns in a freshwater tidal wetland. Amer. J. Bot. 72: 161-174.

Pielou, E.C. 1984. The Interpretation of Ecological Data. John Wiley and Sons, New York, New York, U.S.A. 263 pp.

SAS Institute Incorporated. 1985. SAS User's Guide: Statistics, version 5 edition. SAS Institute, Inc. Cary, North Carolina, U.S.A. 956 pp.

Sickels, F.A. and Simpson, R.L. 1985. Growth and survival of giant ragweed (Ambrosia trıfida L.) in a Delaware River freshwater tidal wetland. Bull. Torrey Bot. Club 112: 368-375.

Sifton, H.B. 1959. The germination of light-sensitive seeds of $T y$ pha latifolia. Can. J. Bot. 37: 719-739.

Simpson, R.L., Good, R.E., Leck, M.A. and Whigham, D.F. 1983. The ecology of freshwater tidal wetlands. BioScience 33: 255-259.

Stebbings, R.E. 1970. Recovery of salt marsh in Brittany sixteen months after heavy pollution by oil. Environ. Pollut. 1: 163167.

Stickney, R.R. 1984. Estuanne Ecology of the Southeastern UnIted States and Mexico. Texas A and M University Press, College Station, Texas, U.S.A. 269 pp.

West, D. and Whigham, D.F. 1975-1976. Seed germination of arrow arum (Peltandra virginica). Bartonia 44: 44-49.

Whigham, D.F. and Simpson, R.L 1975. Ecological Studies of the Hamilton Marshes. Progress Report for the Period June 1974-January 1975. Rider College, Biology Department, Lawrenceville, New Jersey, U.S.A. 185 pp.

Whigham, D.F., McCormıck, J., Good, R.E. and Simpson, R.L. 1978. B1omass and primary production in freshwater tidal wetlands of the middle Atlantic coast. pp. 3-20. In: Freshwater Wetlands. Edited by R.E. Good, D.F. Whigham and R.L. Simpson. Academic Press, New York, New York, U.S.A. 378 pp. 